of Functions" (1944). During the First and Second World Wars, he solved a number of mathematical problems directed to what he called trivial purposes. In the former of these two periods he was a second. lieutenant in the Royal Artillery; but it may be assumed that he avoided the menial tasks which usually fall to subalterns.

Littlewood is a legendary rather than a public figure; when he has travelled abroad, it has been for athletic interests and not to talk mathematics. But he has started many young men in research. They get from him no gifts of easy problems, but boundless encouragement to try the hard ones: "If you don't solve that problem, it will lead you on to another one". Elected to the Royal Society at the age of thirty, he received a Royal Medal in 1929 and the Sylvester Medal in 1943. In making the latter award, the President of the Royal Society said: "He was the man most likely to storm and smash a really deep and formidable problem : there was no one else who could command such a combination of insight, technique and power".

\section{Mathematics at Cambridge :}

Mr. A. S. Besicovitch, F.R.S.

Mr. A. S. Besicovitch, who succeeds Prof. Littlewood, began research in Russia under the famous Markoff. He left Russia in 1925, and with a Rockefeller studentship worked in Copenhagen and Oxford for two years. After a year as lecturer at the University of Liverpool, he was appointed to a lectureship at Cambridge; he has been a fellow and lecturer of Trinity College since 1930. He was elected to the Royal Society in 1934. Besicovitch is a 'real variable analyst'. His work is normally as austere as it is distinguished, and by temperament he avoids the limelight, but dramatic surprises pursue him. $\mathrm{He}$ has recently exploded a long-accepted theory of the area of a surface. This is a highly technical matter; but two other surprises are intelligible to the layman. In 1927 there was the following unsolved problem : Find a figure of least area within which a segment of unit length can turn through $360^{\circ}$ in continuous movement. Everyone accepted the common-sense solution of a 3-cusped hypocycloid of area $\frac{1}{8} \pi$. Besicovitch's solution, however, is that the figure can have arbitrarily small area $\varepsilon$; it grows infinitely complicated as $\varepsilon \rightarrow 0$ and spreads towards infinity in all directions (Math. Z., 27, 312). The second example is actually a re-discovery $(J$. I ondon Math. Soc., 22, 285) of a forgotten result by Tietze of 1905 ; but it is a perfect foil to the first: What is the maximum number of convex polyhedra, nonoverlapping, and any pair having contact over a positive area? (The corresponding number in two dimensions is 4.) Having annihilated an area the first time, Besicovitch has now done the opposite; for this answer is infinity.

\section{T. G. Masaryk (1850-1937)}

MARCH 7 is the centenary of the birth of Thomas Garrigue Masaryk. Born of humble parents at Hodonin in Moravia, he served as an apprentice first to a Vienna locksmith and then to a country blacksmith before a local schoolmaster arranged for his entry into the secondary school at Brno, the Moravian capital, in 1865 . In 1872 he matriculated at the University of Vienna and studied philosophy, graduating as $\mathrm{Ph} . \mathrm{D}$. in 1876. After an anxious period as a lecturer in Vienna, Masaryk was appointed professor of philosophy at Prague when the University was re-organised in 1882. From that time until 1914 Masaryk wrote and lectured on philosophical subjects with the object of promoting Czech culture, especially as regards modern trends. He founded the daily $\mathrm{Cas}$ ('The Times') and himself conducted its weekly science column. From time to time he became involved in philosophical disputes and in political controversies and was thrice elected to the Austrian parliament. In 1918 he was elected first president of the Czechoslovak Republic, and with Ben€ š. his son Jan Masaryk, and others, achieved a good measure of success, especially in culture and technology, in both of which Masaryk himself was keenly interested. The University of Brno, founded in 1919, bears his name, and so does the Masaryk Academy of Work, which sponsored many scientific and engineering projects. It seemed as if Czech science and learning, with sound traditions rooted in the past, was at last attaining the success it deserved, when the State was first dismembered and then occupied by the Germans in 1939. Masaryk's spirit, his insistence upon the force of the Hussite motto, "Truth Prevails", and his influence still remain to inspire the nation afresh in its struggles against adversity.

\section{Geological Society : Foreign Members}

The following have been elected foreign members of the Geological Society : Prof. J. Cadisch, professor of geology, University of Berne ; Prof. C. O. Dunbar, professor of palæontology and stratigraphy, Yale University; Prof. R. F. Flint, professor of geology, Yale University; Dr. P. A. Geijer, director of the Geological Survey of Sweden; Prof. M. Gignoux, professor of geology and mineralngy, University of Grenoble ; Prof. L. C. Graton, professor of geology, Harvard University; Prof. A. Heintz, professor of palæontology, University of Oslo; Prof. R. Richter, professor of geology and palæontology, University of Frankfurt; Prof. A. S. Romer, professor of zoology, Harvard University; Prof. L. Störmer, professor at the Palæontological Institute, Oslo; Prof. T. Vogt, rector of the Norges Tekniske Högskole, Trondheim.

\section{Journal of the Optical Society of America}

BegINNING with the January 1950 issue, Dr. Wallace R. Brode, associate director of the United States National Bureau of Standards, succeeds Prof. G. R. Harrison as editor of the Journal of the Optical Society of America. Dr. Brode has been for several years a director of the Society and an associate editor of the Journal. In an editorial to the December 1949 issue of the Journal $(39,979)$, Prof. Harrison pays tribute to his successor and remarks on the rapid growth, both in size and numbers printed, of the Journal during the past decade. The number of subscribers, now 3,700, has almost trebled; and the increase in size of the Journal is illustrated by the fact that when Prof. Harrison took over the editor. ship ten years ago it was his ambition to average sixty-four pages per issue; but now his successor will have to tackle the pressing problem of the limitation of each issue to the ninety-six much larger pages allowed for in the 1950 budget of the Society.

\section{Science for Farmers}

Criticisms have recently been made that little progress is being made in the teaching of science in adult education classes despite a widespread interest in current science among members of the general public. These criticisms are well founded, and it is 